\title{
Re-defining Modernity and Development Dimension in Quest of Indigenous and Ingenuous Prosperity of Himalayan Region
}

\author{
Atindra Dahal \\ Kathmandu School of Law, Bhaktapur, Nepal \\ fan2mefriend@yahoo.com
}

\begin{abstract}
At this time, all the countries around the globe- regardless of size, location, political variation and differences of the past legacies- are actively engaged and have incessantly exhibited a deep penchant into discourse of development. This article tries to path find the most acceptable notion of development along with demarcation of Himalayan region. Furtherance, this writing explores way-out for the very region's development by evidently detaining and vanquishing the existing hindrances and noticeable hurdles, which have often plunged and forged the profound prospects of sound organic developmental gain regularly towards a dauntingly downward trajectory since long.
\end{abstract}

Keywords. Development, Himalayan Region, Stigma, Gains, Prosperity

\section{Methodology}

Being a purely qualitative academic research, this paper makes an extensively inclusive review of many published literature to build core conceptual framework. Then, it tallies those versions, which the various scholars have raised, in quest of deriving researcher's conviction and inferring the argument. The set of conclusion and crux of the ultimate polemic developed by this paper is escorted and assisted by already published pieces; hence, it adopts the method of descriptive discussion along with interpretive paradigm.

\section{Background}

Development is an evidently endless wait and an anxious cum desperate expectation of the people, everywhere. No any exact and flawless definition of development has been yet developed and possibly can be succeeded to do so in the future. Still all the countries are deeming it as preordained action; and lacking of it is assumed as abysmal situation rather. No development initiative stifles and asphyxiates the mass as ensuring it definitely and deeply luxuriates all. Hence the discourses of development, along with debates on it and waysforward to ensure and endorse it, have been always much enticing and appealing domains to drag the mass limelight of from person to public across the globe.

The notion of development may appear in different forms and ranges to various sectors from society to culture to technology to science and so on. In course of perceiving development, Thomas (2000) deems it as threefold process since vision, action and historical 
process should concur whereas Antonio (2009) prioritizes on 'pacifying conflicts among different interest groups'. Having quite other way round understanding, reducing shortage and availing amenities denotes development for Blackman (2006); generating monetary values in real terms falls as most preferred indictor for Chateau et al (2011); developing cities and recycling economic status of people means a lot for Diaz (2011) respectively- while fixing and tallying the development determinants. Thus it lucidly looms large and swells vague. But gaining it is terrific and intriguing to one and all around the globe. Galor and Moav (2004) identify the replacement of physical capital accumulation with human capital accumulation as most apparent siren and sign of development among other any indicators for it.

Despite having not any solid and universal parameter, economic prosperity and financial fortification along with bracing economic status of nation are tailored to be the most decisive and paramount benchmarks of development. Bourguignon (2003 \& 2005), in regard to a study related to Egyptian case, confirms the mathematical nexus between growth flexibility of poverty reduction and the initial inequality followed with the location of the poverty line in lieu to mean incomes. Ravallion and Chen (2003) propound a pro-poor growth measure namely 'growth incidence curve' (GIC) in the very domain. After working out in system called 'Poverty Equivalent Growth Rate' (PEGR), which embodies distributional concerns, Kakwani and Son (2003) \& Son (2004) propose a supposedly 'more conclusive' pro-poor growth index. But each of the attempts was devoted to build more comprehensive and logical tool to find out the crux of poverty thus advising the most modest and surreptitiously successful model of development could be forwarded. The indisputable and unequivocal observation from them is that economic development means and matters unconditionally and sans option. Currently, countries with ballooning economic gains are accomplishing substantially in reducing the pains and are holding the accruing height in global lead. Even though Piketty (2013) and Stiglitz (2012) have some minute and painstaking observations regarding flawed and foul tendency on distribution of economic treasures among people, still economic sufficiency is the key feature and most important factor to protect the hopelessly outnumbered people and fluid situation then lead towards solid and observable stability and growth. Liew's notion (2004) of 'loose hug' in lieu with China's engagement, Haggard's idea (2004) of 'institutional change', Sen's notion (2000) of 'freedom' and Sachs's views (2005) on 'development as the end of poverty' are all then go only possible once rapid rise and gigantic growth in economic aspect takes place in respective country.

Provided being economically sound and smart, all other rights can be auto commanded. Real empowerment is class though caste is highly being prioritized preposterously in identity politics. In the very line, Vaid (2007) notes class being important and writes, "We observe a consistency in the patterns with the overrepresentation of the higher castes in what can be considered the higher classes, and of the lower castes in the lower classes" (P: 24). Thus, caste seems as problem; but she, with data, shows the trend of high class people dominating over low class than on ground of mere caste. Having almost close inference over the issue, Dahal (2016) writes, "Gone are the days that an individual on pretext of caste or ethnicity egoistically or conceitedly practices the discriminative deeds over the person of next caste or ethnicity. Interracial marriages are increasing and no rich is blamed witch" (P: 8). Both authors make a hint that competence over castes and charterer along with kindness are being pivotally decisive decision makers these days. No spat is spewed based on caste and race as responded is thawed referring the caste again. To further endorse the concept, Andrews (2006) finds that skills over race are worshiped in Australia and so do 
Forster (2004) and Hughes (2007) as well to agree in views in regard to the cases of various countries.

Still an economically well-off, irrespective of caste, loves doing so over the one who is deprived or destitute of same financial solvency. The other rights can be exercised if and only if individuals do have capacity to purchase or pay for it. Brighouse and Swift (2016) deem normative implication in family as the result of class (in education of child) whereas Holroyd (2012) talks about employers' discrimination over employees in job fraternity as an implicit bias based on the earning or income it hatches, hails or heralds. As per the studies conducted by Jackson (2009), social elites in terms of economy are understandably more likely to receive response from employers. Bottom top 5\% poor on the basis of income in UK, as Jenkins (2015) says, are always and ever discriminated and such pitfall and suffering, as per Jones (2012), falls mostly over the working class people. Khaitan (2015) assimilates the class as the real privilege whereas Pickett \& Wilkinson (2010) believe it to be the predictive of the income, every respective individual holds. Young (2003) argues that real injustice oozes from the class. Having good economic condition never bars and mars someone on doing so. Hence, it shall not be an exaggeration to generate a synopsis that real sense of development germinates and takes a sound genesis from basing self-built powerful and strong economic development.

Summarily making a rapport on the discourse, Lopez (2004) deems that pro-poor growth focuses solely on the link between poverty and growth as Ravallion and Chen (2004) construe it as an absolute criterion; and Kakwani and Pernia (2000) consider the poverty ought to be not always viewed and conceptualized absolutely rather to be perceived relatively, thus, its folds and fathoms can be explicitly observed.

Economic strength enables nation to extend then enlarge the influence and leverage over others. Thirtle et al (2003) have analyzed data of 59 countries besides Tiffin and Irz (2006) have replicated the same in 88 countries adopting an econometric model. All of these studies invariably and infallibly draw an identical gist that real development that people love and live with is piggybacked hugely with economic sufficiency and growth. No other properties of nation shall be decisive obligation for it thus even tiny nations have accomplished on doing it. No well-off shall be shunned or dominated in other traits. Thus, everybody earnestly wills and tries for the same. All countries' governments dare and devise best plan to buttress and bolster the pace of economic development in nation. Every election campaigners pithily and with plethora of focus lay the stress on harboring gigantic economic success. Tall promises, though performance may be quite and understandably dismal often, are always the best tool to hypnotize then canvass people. Byerlee et al (2005) have summarized the findings of 12 country case studies on 'how to operationalize pro-poor growth' and have sailed to a sound gist that only economic empowerment is the one and only option for it. Hence people love to build and embryo perception towards government on the startlingly widened sterling worth of government to ensure competent compass of economic development in respective nation. In case the rulers ensure appreciative pace of economic development then mark an exceptionally exponential finical growth, mass public pass vivacious and positively valued remarks. Taking the reverse gear gives people much rational and reasonable ground to vilify the government. The regime succeeding to make far reaching economic prosperity garners the mass as an avid and ardent sympathizer or supporter but taking a reserve direction minutely mars the public sentiment as well. Poor economic status relegates the nations into helplessness and all-round gridlock then seriously jeopardizes its natural growth as well. Often they have to capitulate to others for development and sometimes should bear the brunt of dicey and dismally derogative deeds. Such nations often 
metamorphose to mob of maladroit people and undergo a draconian devastation. Even Loard Buddha is said to have preached that the poverty is the highest foul and ulcerous folly to weaken any nation. Poverty turns to be their greatest weakness and most easy point to wreck any nation. Thus, an undivided focus is being paid to ensure a rapid and robust pace of economic development, everywhere.

Adams (2000) assumes that any country's economic income increment shall pay crucial role to deduct and reduce the poverty thus to emboss better life for people. Among data from various countries, he infers that 10 percent growth in economic income assists to reduce poverty and deprivation by 20 to 30 percent. Lin (2003) finds China lifting 450 million pro-poor people into privileged economy since 1985 to 2001 whereas Bhanumurthy and Mitra (2004) trace similarly gigantic and galloping growth of India after 1990; and Arndt and Simler (2006) claim of 62\% of economic growth in Mozambique between 1996 to 2002 . Furtherance, Kapsos (2005) notes creation of many jobs in Middle East, East Asia and subSaharan Africa after 2000 as their ability to gain economic development and leading for further development. The whole quality of human lives has been improved. Such economic growth positively drives human development and ensures comfort and content in human mind as well. Wilhelm and Fiestas (2005) drag many such examples from Vietnam where increasing economy made changes in school attendance, curtailing health hazards and so on. Every single in particular and entire gamut of studies as general have succeed to emboss and endorse an irrefutable and indisputable fact that economy is the deeply decisive and foremost indicator of development anywhere.

Owing to very assimilation, all the countries in alone and with many of regional and global cooperation and corroboration are immersing to alleviate stringent status of poverty and ameliorate the mass lives. Economic freedom is urged and deemed as most cardinal and cordial achievement to go on to the tag. Being guided with deep penchants to the development and rendering it as sine qua non, inter alia other aspects, multipronged engagements are taken into active adoption and exercises. Deaton and Dreze (2009) believe that being poor or rich unleashes converse relation on being developed thus producers countries have been able to enjoy it. Dvir and Rogoff (2009) note level of income, as Hsieh and Klenow (2007) feel to be backed with heavy investment and employment generation, being auto-correlated to the status of development. It is regarded as development of development or growth of growth rather.

Alike other countries, Himalayan region has always aimed it i.e. exponentially massive economic success with high focus. The elegant essence of being developed is fairly garnered and every nation in this region has been striving to upgrade self from plummeting and exacerbating economic conundrum or at least has deeply assimilated the mystery of mission. Hence they have internalized to unleash and deliver the best of what they can do in the noble quest of economic development. Hence, economic development is one of must mandatory aim of the Himalayan region and countries ought to mire on it unconditionally to position themselves into front of developed nations.

\section{Himalayan Region}

As a special topography and queer composition on the earth, a mountain range in Asia that has stretched between the plains of Indian subcontinent and Tibetan plateau is popularly known as the Himalayan Region. To further clarify and elaborate it, Neggi (1998) writes, "the Himalaya are the most magnificent feature on the surface of the earth" (P: 1). The very region consists of many of earth's highest peaks roughly about 50 in number, including the highest one, Mt. Everest as well. Some scholars even demarcate the area having 
subduction of Indian tectonic plate and Eurasian plate as the Himalayan region. On north east, it is bordered from Karakolam to Hindu Kush region and up to the plateau of Tibet on the north. The range which is commonly and understandably seen as 'abode of the snows' and 'of twenty-five global biodiversity hotspots (Chalise and Khanal: 2001) is known as the Himalayan region; and it is, at the same time, a grand display of great climatic variability and rich biodiversity.

As reported and surveyed sporadically, this region has been an inhabitation for 52.7 million people tentatively, however, the exact figure may slightly mismatch as per varying nature and time of the studies. Hence the human population estimates for the region range from 47 million as per Zurick et al. (2006) to 70 to 90 million in lieu with the studies by Ives and Messerli (1989) to 210 million apropos to a survey conducted on behalf of ICIMOD (2011).

Comprised of five major countries namely Nepal, India, China, Bhutan and Pakistan with relatively less coverage from other three nations as well namely Bangladesh, Afghanistan and Myanmar as well, this region embodies a great reflection of south Asian mythology, religion, literature and so on. As per ICIMOD's reporting in 2011, the Himalayan mountain range covers an area of roughly 600,000 square kilometers, extending 2,500 to 3,000 kilometers in a roughly east-west arc.

This region, having various types of Himalayas and peaks, stretches uninterruptedly about 1500 miles in length in major five countries. Being further extended up to $3500 \mathrm{~km}$, slightly it has a connected expansion from Afghanistan to West Myanmar including Bangladesh as well. Among all, Nepal is only one which has exceptional bliss of being blessed to have its entire territory of northern belt in an uninterrupted series of Himalayas. Himalayas are known popularly as 'third pole' (Schild: 2008) and the 'water tower of Asia' (Xu et al: 2009). Besides, those directly or indirectly affect lives and livelihood of over 300 million people (Schild: 2008) on what Armstrong (2010) and Kargel et al. (2011) too cede sans any objection and reservation. On the reason of differences in nature, often the whole Himalayan range is re-stratified as greater Himalayas, lesser Himalayas and outer Himalayas, respectively.

Standing boundlessly rich and princely equipped in bio-diversity, this region is an abode for many thousand types of wild lives, most sacred Flora and Funna, hugely important lifeline of people, rivers and glaciers and so on. This region encompasses cold, rough topography, rocky and corrugated surface with snow clad mountains and hills, which originate many seas of the world. Mukherjee and Sachan (2003) regard this area as 'rich rocks' and (Valdiya: 2010) confirms it of being greater than $3500 \mathrm{~m}$ in length. As per the studies from Owen et al (2002) and Dyurgerov and Meier (2005), highly glaciated areas outside the Himalayas build the base of boundless water power and resource for the worldly livings.

Despite breathtaking and spectacular natural luxury and abundance, yet the economic development seems stand still and slackening back in most of the countries lying across the region. There are many prominent reasons and unprofitable cases and causes for the same.

\section{Status of Stigma and its Core Causes}

Among other harrowing factors to decay and dismay the development prospect of this region, accruing and acrimonious political instability places itself as a top-most tangible reason. The nations having relatively stable politics seem capable to usher the good activities as well as to command the respect and cooperation from public as well. Regularly irregular stability pullulates bedlam and germinates profound pandemonium. Such chaos has always 
diverted and drifted the major concern away from development. Shonchoy \& Tsubota (2014) note that instable nations grow fragile and conflict-ridden by having the attention largely drifted away. In course of related studies, Memon et al (2011) regard stability as the base for nation building whereas Giskemo (2012) feels socio economic inequality and instability to have converse relationship. After study of 169 countries from 1960 to 2004, Rashid (2012) has drawn much matching inference. Hartal in Bangladesh increased per year 10 times from 1970 to 2010 thus causing serious and dismal damage on the economy, trade and employment respectively; and the whole bundle of bad-luck was credited to instability and bedlam. Campbell and Saha (2013), and Zhang et al (2009) find instability breeding corruption and instilling bribery and embezzlement; whereas Aisen and Veiga (2010) conclude that instability reduces economic policy making. Qureshi et al (2010) have found out the negative correlation between political instability and economic improvement. Kouba and Grochová (2011) also have used the single equation model and noted symmetrical outcome in lieu with the findings inferred by the aforementioned scholars and researchers.

Cerra et al (2013) call instability as disruptive events leading to currency crisis as claimed by Cavallo et al (2013). And the very instability further leads to counterinsurgencies (Singhal and Nilakantan: 2016), civil wars (Bove et al.: 2016), trade openness (Nannicini and Billmeier: 2011), economic liberalization (Billmeier and Nannicini: 2013), natural resource discoveries (Smith: 2015), inflation targeting (Lee: 2011), natural disasters (Cavallo et al.: 2013) and fiscal consolidation (Kleis and Moessinger: 2016), respectively. Most of countries in this region for long have surfed into many editions and episodes of unendingly recurring political instabilities. Nepal underwent 36 government shuffles in last 30 years; Bangladesh had massive and minute political turmoil; Pakistan is facing regular jig-jag; India too had remarkably frequent changes because of hung parliament, though relatively fair now; Myanmar is reeling under Rohiyga crisis and so on. This instability was making the region plunge into either under dismal or no attention in regard to development. Much of the time is disproportionately consumed in healing political ruffles, addressing the events and political discourses, settling political principles and policies. Even the both fiscal and formal attempts to developmental issues seem getting shrunk and looming distanced in comparison to political issues. Hence this region has been the hub of global poverty, technological backwardness, hugely enforced migration, rampant and rife havoc and so on.

Enforcement of failed political and government model in many Himalayan regions amounts to compound and aggravate the degrading and diminishing curve of development. Parliamentarian model in Nepal, Bangaladesh, Bhutan, Pakistan and India is the copycat of UK and many of European liberal democrat methods, whereas, America and China oppositely differ in nature into a great extent. Sircar (2014) regards copying the western liberal method useful for India hence has accepted to adopt it whereas Bogdanor (1984), quite early, had assumed it as the weapon to de-stable and fluctuate politics perennially. By the time, western hegemony has got extended and enveloped the nations through violence of knowledge as well, Himalayan region's nations are more messed into agendas which are much counterproductive and were west-germinated thus gave a genesis to destabilize situation of Himalayan region. Much aesthetically ennobled Liberalized economy and multiparty democracy with proportionate systems always beget unending restlessness and unequal distribution of wealth and income plunging and plummeting the societies into new height of chaos and turmoil. Always hung parliament comes into composition thus sufficing way out for full-tenure restlessness and cacophony backed with usual and shamefully unusual cum unethical political equations and government shuffles too. In average, a government had changed into from 9 to 12 months in Nepal. Such instability begets poor or negative economic 
growth. Corruption takes height, anarchy and societal restlessness unfold utmost and umpteen then goes floated to the grass roots. Political leadership remains fleeting and bureaucracy goes irresponsible and unaccountable. Planning and policy fluctuation germinate the mass uncertainties and pessimist worldviews. Sangroula (2019) too agrees on essence of the message and writes, "one should not, however, forget, that the main cause of continuity of this problem is rooted into the liberal political structure itself that survives on puffs of capitalism, which itself is largely distorted in out times" (298).

Cultural collision among people in Himalayan region has heightened the unwonted confrontation and fracas. The cultural affinity could be promoted for exposure and benchmarked for the new module of business. But in name of identity politics, it has been projected as the baseline of demarcation and differentiation thus building division. Akerlof and Kranton (2000) trace the identity of economic strength and self-image into development. People here are more divided and split in name of religion, language, culture, ruling modality and many other secessionist political issues which are evidently provocative and harmful. The western policy of rival societies has impregnated people with sense of jealousy, sense of difference and alienation rather. Often, the natural and inherited characteristics have been misappropriated for division and discord in society. Runciman (2018) regards the same as the arch reason for end of democracy; and Levitsky \& Ziblatt (2018) too rate the same but lay focus on character.

Civilian division among people and rift and rancor among mass equally credits societies to be ever hostile and helpless at whole. Besley \& Reynal-Querol (2014) believe that local conflict and confrontation ultimately develops in form of the conflict and civil war. Ghani and Lockhart (2008) draw negative relation between conflict and division among people and curve of development. The state of split mind and hostile feeling among public and brazen mockery towards each other, sheer and apparent mutual-non-tolerance have seriously harmed and smashed the unity, strength and possible efforts to be discharged for the development.

Anti-eastern mindset of development and self-projection of inferiority have been most heinous and horrendous hurdles. People mostly underrate and devalue themselves in comparisons of the west. Having illogical and unjust obsession or infatuation to copycat the west in name of development has forced them remain ever in the state of pauper and penury. Excessive migration towards the west, unjust and endless infatuation or hype towards education in west and so on have ruthlessly jeopardized the development prospects tremendously, causing serious lack of mentality as well as human resources as well.

Political intervention and big-brother attitude of some powerful countries of the globe have often and noticeably intervened and halted the regular pace of development in some nations across the Himalayan region. America is trying to develop and usher the international policies sans consultation with respective stakeholders. Ugly business of peace and ammunitions supply, by the nations in disguise of peace promotion, has passed the venom in the nations across the Himalayan region and caused us face many grandiose intentions.

Generation of rival strategy, as brain child of pompous and overtly romanticized arrogance of western nations, has often engaged and obligated nations remain in battle of different modes than having concentration in development of self. Sangroula (2019) vividly observes the rival strategy that America is conceitedly and vehemently posing against India and China with purpose of containing China. Feeling as pivotal concept to Asia and attempting to rebalance one another often serves to spoil self to the greater end.

Being sacred of Thucydides trap and reflection of perceived defeat and failure have collectively forced and compelled the nations to conspire and plot against the rising nations. 
Those, who fail to succeed, endeavor to crash others than building self. Such conceited bemoaning and baseless bewailing of America seems activated to wreck and wry the Himalayan region nations, especially China. Containing one against self and then provoking rest against that is what the west is engaged for. Allison (2017) defines that Thucydides Trap as a new form of battle for business. And Himalayan region based nations are deeply and in blindfolded manner mobilized in the very course sans being comparative enough on the pros and cons of it. Thus, it is almost about to be late to realize the loss and remodel or reconfigure themselves from the location of profound pains to moment of good gains.

\section{Remodeling the Pain into Gain}

In order to evacuate nations from this agony and ignominy, an exhaustively purified economic model from broker-based to production based should be adopted. Wade (2004) believes that sharp decline on global population of poor society is all because of production based economic growth. In sub Saharan region Africa, people living below 1.08 \$ per day came down from 1991 to 2008 by 50 percent. As an outcome of notable growth on industries and similar issues, Timmer (2004) regards similar progress in Indonesia. Srinivasan (2004), commenting in regard to China and India, infallibly drags a conclusion that the miracle in development they are pursuing is all because of their ingrained obsession to produce in self and sell to others what for Ravallion and Shen (2003) call an uneven progress trend. BRI and AAGC modality are as prime modus operandi and implemented with highest sense of quivive. Liang and Mei (2005) feel its spillover effect on Taiwanian growth as well as Helpman (2004) notes that development in one nation unknowingly underpins the same culture in surrounding and adjacent countries as well.

Therefore as many as possible industries should be established. Falling to rentseeking attitude of developed country should be painstakingly gainsaid. Purchasing others' products and selling it with high profit in between makes nation always be debt-trapped. Unless, production is prioritized over mere profit, it always makes nation poor and widens the gap between rich and poor. That creates further injustice. Thus production should be prioritized that makes countries to hold capital in themselves. National economy shall be strongly regulated and steered within the nation. Public should be encouraged for consumption of in-house production than foreign goods and services; a smart orientation to discourage capital flight in any respect and excuse should be functionalized. Every sector from agricultural to tourism should be deeply modernized and commercialized.

People have cautiously begun to mark this time as the Asian century as Asian nations have started to delightfully and dominantly control over the world export. China has leap giant biggest trade surplus in the world graph; hence it has been a superpower quite sooner. The whole mystery behind tricks of success is high production and global supply. Every nations across should endeavor the same.

Export versus import shall be another panacea. Unless an aggressive export based business model shall be adopted to balloon the trade surplus, no country can thrive and prosper. All the developed nations have accomplished to achieve a heightened trade surplus. So should be our aim and objective too. Ferreira and Facchini (2005) note the rapid and robust expansion of industries as the most powerful boost to ensure the expected height; and the same is noted as the arch reason for India, South Korea, Brazil and Mexico to be as some of countries of exponentially exceptional economic growth and development in last decade as published by Economist Intelligence Unit. Dollar and Kraay (2004), thus, lay a serious stress on expansive export based trade. China, Germany, Rusia and South Korea, the world's 4 largest trade surplus countries, have been able to set far reaching development in last decade. 
Ahya and Xie (2004), therefore, regard China as Asian tiger. Many of Asian nations are in the trend, thus, the future is with Asia. Very passion of making a huge export has to be assimilated and exercised by the nations across the Himalayan region.

As foreign helps and missionary assistance in different names have been ruthlessly decimating the indigenous economic and developmental possibilities, a stern push back trend should be adopted. No nation can thrive on mercy and assistance of others. Observing the impacts over many African nations from Somalia to Ethiopia, Brautigam \& Knack (2004) find hugely existing tangible evidences for negative impact of foreign aids on growth as Coyne (2013) has inferred. Browne (2006) believes that it grossly fails to meet developmental need as the size and direction of allocated aids are subjectively determined by donors. Brumm (2003) has found weak institutions and bad policies as major ground of aid's failure though Calderisi (2006) believes that internal rivalry and conflicting objectives, alike the arch reasons as deemed by Hillhorst (2002), are other issues to derail it. Furtherance, Drazen (2007) notes that the aid agencies are completely aloof and hugely indifferent towards the core needs of purportedly targeted people. Eric (2008) too observes then accepts the same. Leeson (2008) boldly remarks that foreign aids have quantum fiasco. Moyo (2009) regards that guest supply slow-poison through aids to deliberately sabotage the possible organic model of development whereas Easterly (2003) too notes the perceived superiority of white men to rescue and rebuild the East. Thus, No INGOs or a big No INGOs policy, though seems difficult initially, saves nation from growing state of being paralyzed hence taking a leak and leap forward towards an anticipated development is must. Most of these NGOs and INGOs are actuated and activated to annihilate the soothing and organic possibility and prospect of the receiving nations. Breeding violence, pullulating passivity and building indolence and parasitic nature on public are few notable, ulterior and cancerous outcomes of these institutions. They often fragment the society, instill havoc and lead to disorder in name of development. Mostly they plunder resources and pollute the self-built culture. Their assistance will be only earmarked in salary and allowance of their high official who bound from the host country itself. Thus destroying the devilish network of I/NGOs and wrecking the insensible interest to injure and impede the virgin possibility should be adlib adopted sans any alibi.

Smart mindset formulation among people is most modest and powerful panacea. Unless, mind is changed, not any other change shall be possible either to imagine or to execute. The poor mentality compounds the exacerbating and deteriorating situation (Bartle: 2013), and even Tran (2012) locates that, besides environmental, mental issues are also quite important. Baddeley (2013) regards socio-economic phenomena based on mindset, self-view and world-view as much profitable praxis alike Bénabou \& Tirole (2016) and Borjas (2016) value positive mindset and positive contribution on the same note. Burnette et al (2013) regard mindset as key determinant and factor; and Dweck (2006) has propounded the theory of growth and fixed mindset in the same pretext. Thus, such public mindset is to be developed that mass will be ready to produce something and sell over to purchase. Provided, an utmost sense of producing swaps the suicidal scene of purchasing, it best evacuates any nation from reeling under poverty. Harari (2018) regards having mental equanimity and competence as most powerful weapon to overcome and outvote any of challenges; and Himalayan regions nations should own and earn it. Denying copycat of the west, the remodeling of self is must.

\section{Conclusion}

Hence, the languid and fractured development dynamics in nations across the Himalayan region seems to have some definite reasons for having this haplessness and helplessness. If some efforts and attempts are triggered as discussed above, the expectation of 
having smart and smooth self-based development seems not far beyond the reach. Innovative commencement should be commendably executed anon; the success seems secured and safe.

\section{References}

[1] Adams, R. (2002). "Economic Growth, Inequality and Poverty: Findings from a New Data Set." Policy Research Working Paper, 2972. World Bank, February.

[2] Ahya, C. \& Xie, A. (2004). "New Tigers of Asia." India and China: A Special Economic Analysis. Morgan Stanley, July 26. P+ 59.

[3] Aisen, A. \& Veiga, F. J. (2010). "How Does Political Instability Affect Economic Growth?" IMF Working Paper, 11-12. P+ 22-50.

[4] Akerlof, George A. \& Kranton, Rachel . (2000). "Economics of Identity." Quarterly Journal of Economics, 115. P+715-753.

[5] Allison, Graham H. (2017). Destined for War: Can China and America Escape Thucydides Trap? USA: Houghton Mifflin Harcourt.

[6] Andrews, B. (2006). "Stay-at-home Accounts." Business Review Weekly. Australia: August 3-9. P+ 64...

[7] Antonio, E. (2009). Profiles of Tools and Tactics for Environmental Mainstreaming. Council for Sustainable Development, No 11, www.environmentalmainstreaming.org.

[8] Armstrong, R. L. (2010). The Glaciers of the Hindu Kush-Himalayan Region: A Summary of the Science Regarding Glacier/melt Retreat in the Himalayan, Hindu Kush, Karakoram, Pamir and Tien Shan Mountain Ranges. Kathmandu: ICIMOD. ISBN 978-92-9115-176-9.

[9] Arndt, James \& Simler, Kenneth R. (2006). "Has Economic Growth in Mozambique Been Pro-Poor?" Food Consumption and Nutrition Division Discussion Paper, 202.

[10] Baddeley, M. (2013). Behavioural Economics and Finance. London: Routledge.

[11] Bartle, P. (2013). "Factors of Poverty: The Big Five." Community Empowerment Collective. Retrieved September 5, 2014, from http://cec.vcn.bc.ca/cmp/modules/emppov.htm

[12] Bénabou, R. \& Tirole, J. (2016). "Mindful Economics: The Production, Consumption, and Value of Beliefs $\uparrow . "$ Journal of Economic Perspectives, 30(3). P+ 141-164.

[13] Besley, T. \& Reynal-Querol, M. (2014). "The Legacy of Historical Conflict: Evidence from Africa." Political Science Review, 108. P+319-36.

[14] Bhanumurthy, H. \& Mitra, H. (2004). "Economic Growth, Poverty, and Inequality in Indian States in the Pre-reform and Reform Periods." Asian Development Review, Vol. 21, no. 2. $\mathrm{P}+79-99$.

[15] Billmeier, A. \& Nannicini, T. (2013). "Assessing Economic Liberalization Episodes: A Synthetic Control Approach." The Review of Economics and Statistics, 95(3), 9831001. http://doi.org/10.1162/REST a 00324.

[16] Blackman, A. (2006). Economic Incentives to Control Water Pollution in Developing Countries: How Well has Colombia's Wastewater Discharge Fee Program Worked and Why? Washington, DC: Resources for the Future.

[17] Bogdanor, Vernon. (1984). "What is Proportional Representation? A Guide to Issues." Oxford, Martin Robertson, 1984. P+ 46-141.

[18] Borjas, G. J. (2013). Labor Economics. New York: McGraw-Hill.

[19] Bourguignon, F. (2003). "The Growth Elasticity of Poverty Reduction: Explaining Heterogeneity across Countries and Time Periods." Inequality and Growth: Theory 
and Policy Implications. Edited by T. Eicher and S. Turnovsky. Cambridge: The MIT Press.

[20] Bourguignon, F. (2005). "Poverty-growth-inequality Triangle: With Some Reflections on Egypt." Distinguished Lecture Series, No. 22. Cairo, Egypt: Egyptian Center for Economic Studies.

[21] Bove, V., L. Elia \& R. P. Smith. (2016). "On the Heterogeneous Consequences of Civil War." Oxford Economic Papers. http://doi.org/10.1093/oep/gpw050.

[22] Brautigam, D. A. \& Knack, S. (2004). "Foreign Aid, Institutions and Governance in SubSaharan Africa." Economic Development and Cultural Change, Vol.13. P+255285.

[23] Brighouse, Harry. \& Swift, Adam. (2016). Family Values: The Ethics of ParentChild Relationships. New Haven: Princeton University Press.

[24] Browne, S. (2006). Aid and Influence: Do Donors Help or Hinder? London: Earthscan.

[25] Brumm, H. J. (2003). "Aid, Policies and Growth: Bauer was Right." Cato Journal, 23. $\mathrm{P}+167-174$.

[26] Burnette, J. L., E. H. O'Boyle, E. M. VanEpps, J. M. Pollack, \& E. J. Finkel. (2013). "Mind-Sets Matter: A Meta-Analytic Review of Implicit Theories and SelfRegulation." Psychological Bulletin, 139(3). $\quad \mathrm{P}+\quad$ 655-701. doi:http://dx.doi.org/10.1037/a0029531.

[27] Byerlee, Derek, Xinshen Diao \& Chris Jackson. (2005). "Agriculture, Rural Development, and Pro-poor Growth. Country Experiences in the Post-Reform Era." Agriculture and Rural Development Discussion Paper 21. Washington D.C. : The World Bank. P+ 20-21.

[28] Calderisi, R. (2006). The Trouble with Africa: Why Foreign Aid is not Working. New York: Palgrave MacMillan.

[29] Campbell, N. \& Saha, S. (2013). "Corruption, Democracy, and Asia-Pacific Countries."Journal of the Asia Pacific Economy, 18 (2). P+ 290-303.

[30] Cavallo, E., S. Galiani, I. Noy \& J. Pantano. (2013). "Catastrophic Natural Disasters and Economic Growth." Review of Economics and Statistics, 95(5). P+ 1549-1561. http://doi.org/10.1162/REST a 00413.

[31] Cerra, V., U. Panizza \& S. C. Saxena. (2013). "International Evidence on Recovery from Recessions."Contemporary Economic Policy, 31(2). P+ 424-439. http://doi.org/10.1111/j.1465- 7287.2012.00313.x.

[32] Chalise, SR \& Khanal, NR. (2001). "An Introduction to Climate, Hydrology and Landslide Hazards in the Hindu Kush-Himalayan Region." Landslide Hazard Mitigation in the Hindu Kush-Himalayas. Edited by L. Tianchi, SR Chalise, BN Upreti. Kathmandu: ICIMOD. P+ 51-62.

[33] Chateau, J., C. Rebolledo \& R. Dellink. (2011). An Economic Projection to 2050: The OECD "ENV-Linkages Model Baseli. OECD Environment Working Papers, No 41, OECD, Paris.

[34] Coyne, Christopher. J. (2013). Doing Bad by Doing Good: Why Humanitarina Actions Fail? Stanford: Stanford Economics and Finance.

[35] Dahal, Atindra. (2016). “Question of Empowerment: Class or Caste?"The Himalayan Times, Opinion. Edited by Prakash Rimal. Kathmandu: APCA House. December, 16.

[36] Deaton, Angus \& Drèze, Jean. (2009). "Food and Nutrition in India: Facts and Interpretations." Economic and Political Weekly, February 14. P+42-65. 
[37] Diaz, D. (2011). "Impacts of Forest Management Certification in Argentina and Chile." Forest Policy and Economics, Vol. 12, No 7. P+ 497-504.

[38] Dollar, D. \& Kraay, A. (2004). "Trade, Growth, and Poverty." The Economic Journal, 114. P+ 22-49.

[39] Drazen, A. (2007). Discussion of “Are Aid Agencies Improving?" by William Easterly. Economic Policy. P+ 668-673.

[40] Dvir, Eyal \& Rogoff, Kenneth S. (2009). "Three Epochs of Oil.” NBER Working Paper, 14927.

[41] Dweck, C. S. (2006). Mindset the New Psychology of Success. New York: Random House Inc.

[42] Dyurgerov, MD \& Meier, MF. (2005). Glaciers and Changing Earth System: A 2004 Snapshot. Boulder, Colorado, USA: Institute of Arctic and Alpine Research, University of Colorado.

[43] Easterly, William. (2003). "Can Foreign Aid Buy Growth?" The Journal of Economic Perspectives 17, no. 3. $\mathrm{P}+23-48$.

[44] Eric, M. (2008). "Foreign Aid and Growth." Economic Bulletin, 15: 14. P+ 1-14.

[45] Ferreira, P.C. \& Facchini, G. (2005). "Trade Liberalization and Industrial Concentration: Evidence from Brazil." The Quarterly Review of Economics and Finance, Vol. 45. P+ 432-446.

[46] Forster, C. (2004). Australian Cities: Continuity and Change. Melbourne, Australia: Oxford University Press.

[47] Galor, O. \& Moav, O. (2004). "From Physical to Human Capital Accumulation: Inequality and the Process of Development." Review of Economic Studies, Vol.71, 4. Dec. P+ 1001-1026.

[48] Ghani, Ashraf and Lockhart, Clare. ( 2008). Fixing Failed States: A Framework for Rebuilding a Fractured World. USA: Oxford University Press.

[49] Giskemo, Gunhild Gram. (2012). "Exploring the Relationship between Socioeconomic Inequality, Political Instability and Economic Growth: Why Do We Know So Little?" CMI Working Paper, 2012.2.

[50] Haggard, Stephan. (2004). "Institutions and Growth in East Asia." Studies in Comparative International Development 38, 4. P+ 53-81.

[51] Harari, Yuval Noah. (2018). 21 Lessons for the 21 Century. USA: Spiegel \& Grau, Jonathan Cape.

[52] Helpman, E. (2004). The Mystery of Economic Growth. USA: The Belknap Press of Harvard University Press.

[53] Hillhorst, D. (2002). "Being Good at Doing Good: Quality and Accountability of Humanitarian NGOs." Disasters, 26 (3). P+ 193- 212.

[54] Holroyd, Jules. (2012). "Responsibility for Implicit Bias." Journal of Social Philosophy, 43/3. P+ 274-306.

[55] Hsieh, Chang-tai \& Klenow, Peter J. (2007). "Relative Prices and Relative Prosperity." American Economic Review, 97(3): 562-85.

[56] Hughes, T. (2007). "Working Visas doing the Job." The Courier-Mail. Brisbane, Australia: February 17-18. P+ 74.

[57] Ives, Jack D. \& Messerli, Bruno. (1989). The Himalayan Dilemma: Reconciling Development and Conservation. New York: Routledge.

[58] Jackson, Michelle. (2009). "Disadvantaged by Discrimination? The Role of Employers in Social Stratification." The British Journal of Sociology, 60/4 . P+ 669692. 
[59] Jenkins, Stephen P. (2015). "The Income Distribution in the UK: A Picture of Advantage and Disadvantage." Centre for Analysis of Social Exclusion, 186. P+ i-31.

[60] Jones, Owen. (2012). Chavs: The Demonization of the Working Class. London: Verso.

[61] Kakwani, N. \& Pernia, E.M. (2000). "What is Pro-Poor Growth?" Asian Development Review, Vol. 18, no. 1. Asian Development Bank.

[62] Kakwani, N. \& Son, H. (2003.) "Pro-poor Growth: Concepts and Measurement with Country Case Studies." The Pakistan Development Review, 42: 4 Part I (Winter 2003). P+ 417-444.

[63] Kapsos, S. (2005). Employment Intensity of Growth: Trends and Macrodeterminants. ILO.

[64] Kargel, J.S., J.G. Cogley, G.J. Leonard, U. Haritashya \& A. Byers. (2011). "Himalayan Glaciers: the Big Picture Is a Montage." Proceedings of the National Academy of Sciences, 108: 14709-14710.

[65] Khaitan, Tarunabh. (2015). A Theory of Discrimination Law. Oxford: Oxford University Press.

[66] Kleis, M. \& Moessinger, M. D. (2016). "The Long-Run Effect of Fiscal Consolidation on 38 Economic: Evidence from Quantitative Case Studies." Spintan Project, $\quad$ Working $\quad$ Paper $\quad$ Series $\quad$ No. 6. ttp://doi.org/http://dx.medra.org/10.12842/SPINTAN-WP-06.

[67] Kouba, L. \& Grochová, L. (2011). "Financial Crisis, Political Instability and Economic Growth: An Empirical Evidence from the Baltic States." Acta Universitaties, 59(2). $\mathrm{P}+81-88$.

[68] Lee, W. S. (2011). "Comparative Case Studies of the Effects of Inflation Targeting in Emerging Economies." Oxford Economic Papers, 63(2). P+ 375-397. http://doi.org/10.1093/oep/gpq025.

[69] Leeson, P. T. (2008). "Escaping Poverty: Foreign Aid, Private Property, and Economic Development." Journal of Private Enterprise, 23(2). P+ 39-64.

[70] Levitsky, Steven \& Ziblatt, Daniel (2018). How Democracies Die. USA: Crown Book.

[71] Liang, C.Y. \& Mei, J.Y. (2005). “Underpinnings of Taiwan's Economic Growth: 1978-1999 Productivity Study." Economic Modelling, Vol. 22, P+ 347-387.

[72] Liew, Leong H. (2004). "China's Engagement with Neo-Liberalism: Path Dependency, Geography, and Party Self-Reinvention." Journal of Development Studies, 40, 4. P+ 167-192.

[73] Lin, Bo Q. (2003). "Economic Growth, Income Inequality, and Poverty Reduction in People's Republic of China." Asian Development Review, Vol. 20, no. 2. P+ 105-24.

[74] Lopez, H. (2004). "Pro-poor-Pro-growth: Is there a Trade Off?" The World Bank Policy Research Working Paper No. 3378.

[75] Memon, Aslam Pervez, Kiran Sami Memon, Saima Shaikh \& Fahmeeda Memon. (2011). "Political Instability: A Case Study of Pakistan." Journal of Political Studies, Vol. 18, Issue - 1. P+ 31-43.

[76] Moyo, D. (2009). Dead Aid: Why Aid is Not Working and How There is Another Way for Africa. London: The Penguin Group.

[77] Mukherjee, B. K. \& Sachan, H. K. (2003). "Carbonate bearing UHPM rocks from the Tso Morari Region, Ladakh, India: Petro-logical Implications." International Geological Review, 45. P+49-69. 
[78] Nannicini, T. \& Billmeier, A. (2011). "Economies in Transition: How Important Is Trade Openness for Growth?" Oxford Bulletin of Economics and Statistics, 73(3). P+ 287-314. http://doi.org/10.1111/j.1468-0084.2010.00626.x

[79] Neggi, S.S. (1998). Discovering the Himalaya, Vol.1. New Delhi: Indus Publication Company.

[80] Owen, LA, RC Finkel \& MW Caffee. (2002). "A Note on the Extent of Glaciation throughout the Himalaya during the Global Last Glacial Maximum." Quaternary Science Reviews, 21. P+147-157.

[81] Pickett, Kate \& Wilkinson, Richard. (2010). The Spirit Level: Why Equality is Better for Everyone? London: Penguin.

[82] Piketty, Thomas. (2013). The Economics of Inequality. USA: Harvard University Press.

[83] Qureshi, M. N., K. Ali \& I. R. Khan. (2010). "Political Instability and Economic Development: Pakistan Time-series Analysis." Journal of Finance and Economics, 56. P+ 179-192.

[84] Rashid, Mamun. (2012). "Political Economy of Hartal." The Financial Express. Vol 20. Dhaka.

[85] Ravallion, M. \& Chen, S. (2003). "Measuring Pro-Poor Growth". Economics Letters, 78 (2003). P+ 93-99.

[86] Ravallion, M. \& Chen, S. (2004). "China's (uneven) Progress against Poverty."World Bank Policy Research Working Paper, 3408. September 2004.

[87] Runciman, David. (2010). How Democracy Ends. USA: Profile Books.

[88] Sachs, Jeffrey. (2005). The End of Poverty. New York: Penguin.

[89] Sangroula, Yubraj. (2019). South Aisa China Geo-economics. Nepal: Lex and Juris.

[90] Schild, A. (2008). "ICIMOD's Position on Climate Change and Mountain Systems." Mountain Research and Development, 28. P+ 328-331.

[91] Sen, Amartya. (2000). Development as Freedom. New York: Anchor.

[92] Shonchoy, Abu S. \& Tsubota, Kenmei. (2014). "Economic Impact of Political Protests (Strikes) on Firms: Evidence from Bangladesh." Discussion Paper. Institute of Developed Economies Japan External Trade Organizations.

[93] Singhal, S. \& Nilakantan, R. (2016). "The Economic Effects of a Counterinsurgency Policy in India: A Synthetic Control Analysis." European Journal of Political Economy, 45(December). P+ 1-17. http://doi.org/10.1016/j.ejpoleco.2016.08.012

[94] Sircar, Neelanjan. (2014). The Numbers Game: An Analysis of the 2014 General Election. India: Centre for the Advanced Study of India. https://casi.sas.upenn.edu/iit/nsircar.

[95] Smith, B. (2015). "The Resource Curse Exorcised: Evidence from a Panel of Countries." Journal of Development Economics, 116. P+ 57-73. http://doi.org/10.1016/j.jdeveco.2015.04.001.

[96] Son, H. (2004). “A Note on Pro-Poor Growth”. Economics Letters, 82 (2004). P+ 307-314.

[97] Srinivasan, T.N. (2004). China and India: Economic Performance, Competition and Cooperation: An Update." Journal of Asian Economics, Vol. 15 P+ 613-636.

[98] Stiglitz, Joseph. ( 2012). The Price of Inequality. USA: W.W. Norton \& Company.

[99] Thirtle C., L. Lin \& J. Piesse. (2003). "The Impact of Research-Led Agricultural Productivity Growth on Poverty Reduction in Africa, Asia and Latin America." World Development, Elsevier, vol. 31(12). P+ 1959-1975, December. 
[100] Thomas, Allan. (2000). "Meanings and Views of Development." Poverty and Development in the 21st Century. Edited by Allen and Thomas. USA: Oxford University Press, Oxford.

[101] Tiffin, R. \& Irz, X. (2006). "Is Agriculture the Engine of Growth?" Agricultural Economics, 35. P+ 79-89, July.

[102] Timmer, C.P. (2004). "The Road to Pro-poor Growth: The Indonesian Experience in Regional Perspective."Working Paper 38, Center for Global Development, April.

[103] Tran, M. (2012). "The Post-2015 Development Agenda Explained." The Guardian. Retrieved March 21, 2014, from http://www.theguardian.com/globaldevelopment/2012.

[104] Vaid, Divya. (2007). "An Empirical Exploration of the Relationship between

Caste, Class and Mobility in India." Paper for RC28 Meeting in Montreal.

[105] Valdiya, K.S. (2010). The Making of India-Geodynamic Evolution. New Delhi, India: Macmillan Publishers Ltd. P+ 816...

[106] Wade, R.H. (2004). "Is Globalization Reducing Poverty and Inequality?" World Development, Vol. 32, P+ 567-589.

[107] Wilhelm, V. \& Fiestas, I. (2005). Exploring the Link between Public Spending and Poverty Reduction: Lessons from the 1990s. Washington, DC: World Bank Institute.

[108] Xu, J., R.E. Grumbine, A. Shrestha, M. Eriksson, X. Yang, Y. Wang \& A. Wilkes. (2009). "The Melting Himalayas: Cascading Effects of Climate Change on Water, Biodiversity, and Livelihoods." Conservation Biology, 23. $\mathrm{P}+520-530$.

[109] Young, Iris Marion. (2003). "Political Responsibility and Structural Injustice." The Lindley Lecture, 2003. University of Kansas, May 5.

[110] Zhang, Y., L. Cao \& M. S. Vaughn. (2009). "Social Support and Corruption: Structural Determinants of Corruption in the World." Australian \& New Zealand Journal of Criminology, 42 (2). P+ 204-217.

[111] Zurick, David, Julsun Pacheco, Basanta Raj Shrestha \& Birendra Bajracharya. (2006). Illustrated Atlas of the Himalaya. Lexington: University Press of Kentucky.

[112] "Hindu Kush-Himalayan Region." (2011). International Centre for Integrate

[113] Mountain Development (ICIMOD). Retrieved October 3, 2011, from http://www.icimod.org/?q=1137.

[114] Economist Intelligence Unit (2005a), India. Country Profile 2005. $59 \mathrm{P}+\ldots$

[115] Economist Intelligence Unit (2005b), South Korea. Country Profile 2005. $59 \mathrm{P}+\ldots$

[116] Economist Intelligence Unit (2005c), Brazil. Country Profile 2005. 52 P+... [117] Economist Intelligence Unit (2004), Mexico. Country Profile 2004. 60 P+... 